\title{
İzmir İşgali Sonrasında Yunanlıların Batı Anadolu'da İşgali Genişletmeleri ve Bölgede Oluşan Milli Direniş
}

\author{
Doç. Dr. Adnan SOFUOĞLU*
}

\section{$\ddot{O} Z E T$}

Bilindiği gibi Yunanlılar 15 Mayıs 1919'da İtilaf Devletleri adına ve onların korumasında Izmir'e asker çıkarıp işgal ettiler. İşgale karşı Bölgede silahlı bir milli direniş oluştu. Diğer taraftan bu işgal tüm ülke çapında da büyük bir tepki oluşturdu. Bu tepki aynı zamanda Milli Hareketin gelişip güçlenmesine de yol açtı. Yunanlılarla Milli Kuvvetler arasında bir cephe oluştu. Bu strada Bölgede direnişin örgütlenmesi ve Milli Kuvvetlerin desteklenmesi için kongreler toplandı. İşgal sonucu ortaya çıkan bu gelişmeleri İtilaf Devletlerinin İstanbul'daki temsilcileri kaygıyla izlemekteydiler. Bu arada İşal bölgelerini genişleten Yunanlılar Sevr Antlaşmasından sonra da Batı Anadolu'da yerleşme yolunda girişimler başlattılar ve bu yönde uygulamalarda bulundular.

Bu çalışmada, arşiv belgeleri ışı̆̆ında, İzmir işgali sonrasında Bölgede oluşan milli direniş ile Yunanlıların Bölgeye yerleşme girişimleri ve bu gelişmeler karşısında Osmanl yönetimi ve Milli Hareketin tavrı ortaya konulacaktır.

Anahtar sözcükler: Yunan işgali, silahlı milli direniş, Milli Kuvvetler, kongreler, Sevr antlaşmast.

\section{ABSTRACT}

As known, Greeks, on behalf of and under cover of the Allies, landed their troops on Izmir and invaded the city in May 15, 1919. A national armed resistance occurred in the Region against invasion. On the other hand, this invasion caused a big reaction throughout the country. This reaction, at the same time, enabled the Turkish National Movement to expand and strengthen. Between Greeks and National Forces was formed a front. At the meantime, congresses were held in the Region so as to get the regional resistance organized and enforce National Forces.

\footnotetext{
• Hacettepe Üniversitesi Atatürk İlkeleri ve İnkılap Tarihi Enstitüsü Öğretim Üyesi.
} 
Representatives of the Allies in Istanbul were anxiously watching these developments emerged as a result of the invasion. By the meantime Greeks expanding their Invasion territories also started attempts of settling in West Anatolia after Treaty of Sevr and carried out some actions with this purpose.

In this study, under the illumination of archive documents; the national resistance that occurred in the Region after invasion of Izmir, Greeks' attempts to settle in the Region, and attitudes of Ottoman administration and the Turkish National Movement against these developments are going to be exposed.

Keywords: Greek invasion, national armed resistance, National Forces, congresses, Treaty of Sevr.

\section{GİRIŞ}

Osmanlı Devleti 1914 Yılının Ekim ayında girdiği I. Dünya Savaşı'ndan dört yıl sonra 30 Ekim 1918 de 25 maddeden oluşan ve ağır hükümler ihtiva eden Mondros Mütarekesi'ni imzalayarak Müttefikleri gibi savaştan yenik olarak ayrıldı.' Esasında klasik Devletler Hukukuna göre mütarekeler daimi ve devamlı bir statü oluşturan barış düzenini ifade etmezler. Buna mukabil Mondros Mütarekesi'nin hükümleri Osmanlı Devletini asli niteliklerinden yoksun bırakmaktaydı. ${ }^{2} \mathrm{Bu}$ durum Mütarekenin uygulanması sırasında açıkça ortaya çıktı. Nitekim Mütareke uygulamaya girmesiyle birlikte Osmanlı Devleti antlaşmaya uygun olarak birliklerini geri çekti ve terhis etti. Ordunun mevcudu elli bine indirildi. Ulaşım ve haberleşme ile askeri önemi olan maden ve ürünler İtilaf Devletleri'nin denetimine geçti. 6 Kasım'dan itibaren Çanakkale ve İstanbul Boğazları İtilaf Devletleri kuvvetlerince işgal edildi. 13 Kasım'da ise verdikleri söze aykırı olarak aralarında Yunan savaş gemisinin de bulunduğu bir İtilaf Donanması İstanbul'a geldi ve demirledi. ${ }^{3}$ Aynı zamanda bu gelişmeleri, daha I.Dünya Savaşı öncesi ve Savaş sırasında yaptıkları gizli antlaşmalarla aralarında nüfuz bölgeleri olarak paylaştıkları bölgeleri fiilen işgalleri izledi. ${ }^{4}$ Mütareke öncesi sınırlar dahilinde kalan bölgelerin işgalini takip eden devrede hemen Suriye, Lübnan, Irak gibi yeni devletler kurulması

' Geniş bilgi için bkz. Âli Türkgeldi, Mondros ve Mudanya Mütarekeleri'nin Tarihi, İstanbul 1948 s.63; Ahmet İzzet Paşa; Feryadım, C.2 İstanbul.1993 s.7 v.d.;Mütareke metni için bkz. S. 283-286; Yusuf Hikmet Bayur; Atatürk Hayatı Ve Eseri, Ankara 1997 s.167-173; Rauf Orbay; Cehennem Değirmeni, İstanbul 1993 s. 89 v.d.Gotthard Jaeschke; Kurtuluş Savaşı İle İlgili İngiliz. Belgeleri, Ankara 1986 s. 27 v.d. ;Türk İstiklal Harbi,C.1 Ankara 1962 s. 33 v.d.

${ }^{2}$ Hıfzı Veldet Velidedeoğlu; Devirden Devire, C2 Ankara 1975 s. $72-74$.

${ }^{3}$ Geniş bilgi için bkz. Türk Istiklal Harbi C.1 s.57 v.d.

${ }^{4}$ Gizli antlaşmalar için bkz. Yuluğ Tekin Kurat; Osmanlı Imparatorluğu'nun Paylaşılması; Ankara 1986; Oral Sandar, Siyasi Tarih, C.1 Ankara 1999 s.337-341; David Fromkin; Barışa Son Veren Barış, Çev. Mehmet Harmancı,İstanbul 1994 s. 127 v.d. 
çabalarına girişildi ki Mütareke buna da izin veriyordu. Ayni durum Doğu Anadolu'da bir ermeni devleti kurmak, Batı Anadolu'yu ise Yunanlılara vermek şeklinde sürdürülmek istenmekteydi. ${ }^{5}$ Nitekim Lord Curzon 18 Kasım'da Avam Kamarası'nda yaptığı konuşmada “Kürt, Arap, Ermeni, Rum ve Yahudilerin" Türk egemenliğinden kurtarılacağını söyleyecektir. ${ }^{6}$

Diğer taraftan Mondros Mütarekesi'nin imzalanması ve onun uygulanmaya başlamasından bir müddet sonra başta başkent İstanbul olmak üzere Osmanlı Devleti'nde yönetici ve aydın kesiminde ağırlıklı olarak biri, "kesin olarak yenilmiş ve hiçbir karşı koymaya girişemeyecek duruma gelmiş olan Devletin adil olsunlar olmasınlar galip devletlerin insafına, merhametine başvurmaktan başka çaresi yoktur." diğeri ise "yenen devletler adil ve insaflıdır. Wilson İlkeleri'ne güvenerek ve onları ileri sürerek hakkımızı arayarak iyi sonuçlar elde ederiz. Esasen yapacak başkaca bir şey yoktur." şeklinde iki görüş ortaya çıtı. ${ }^{7}$ Bu düşünce ve görüşte olanlar bilahare çeşitli partiler, cemiyetler ve kurumlar oluşturma yoluna gittiler. ${ }^{8}$ $\mathrm{Bu}$ düşünce ve görüşlerle bu doğrultuda teşkilatlanmaların yanı sıra Mustafa Kemal Atatürk Nutkunda belirttiği gibi, "Mahalli Halas (kurtuluş) çarelerine matuf" görüşler doğrultusunda Müdafaa-i hukuk ve Redd-i İlhak Cemiyetleri oluşturulmaya başlandı. Bu cemiyetler oluşabilecek işgaller karşısında özellikle Yunan, Rum ve Ermenilerin faaliyetlerine karş1 silaha başvurmayı da göze almaktaydılar. ${ }^{9}$ Nitekim İzmir' in Yunanlılarca işgal edileceği haberlerinin alınması ve aynı zamanda bölgede Rum çete faaliyetlerinin artması üzerine İzmir'de Vali Vekilliği sırasında Nurettin Paşa'nın gayret ve girişimlerinin de etkisiyle Vali Tahsin Bey (Uzer) döneminde Aralık 1918'de Müdafaa-i Hukuk Cemiyeti resmen kurulacaktır. ${ }^{10}$

\section{IZZMIR'INN YUNANLILAR TARAFINDAN İŞGALI}

Daha I. Dünya savaşı devam ederken İtilaf Devletleri 12 Nisan 1915'te Yunanlılara, derhal savaşa girmeleri şartıyla İzmir'i vermeyi vaat etmişlerdi. Ancak Yunanistan'ın savaşa katılması hemen gerçekleşmediğìnden ve bilahare İtalya'nın İtilaflar safına katılması sonrasında 19 Nisan 1917 tarihli St. Jean de Maurienne Anlaşmasıyla Rusya'nın da onaylaması şartıyla İtalyanlara bırakılmıştı. Şimdi ise yani

${ }^{5}$ T.I.H.(Türk Istiklal Harbi); C.1 s.16-17; Atatürk'ün Tamim Telgraf Ve Beyannameleri (A.T.T.B.) C.4 Ankara 1991 s.21-22; Bayur; a.g.e. s.178 v.d. Paul C. Helmreich; Sevr Entrikaları, Çev. Şerif Erol İstanbul 1996 s.27 v.d.

${ }^{6}$ Jaeschke; a.g.e. s.36 v.d.; Selahattin Tansel; Mondros'tan Mudanya'ya Kadar, C.1 Ankara 1973 s. 90 v.d.

${ }^{7}$ Bayur; a.g.e.s.191-193; Tuncer Baykara; Milli Mücadele, Ankara 1985 s. 33-35.

${ }^{8}$ Bayur; a.g.e. s.193 v.d.; Ayrıca geniş bilgi için bkz. Tarık Zafer Tunaya; Türkiye'de Siyasal Partiler C.2 İstanbul 1986.

${ }^{9}$ Bayur; a.g.e. s. 209 v.d.

${ }^{10}$ Geniş bilgi için bkz. Celal Bayar; Ben de Yazdım, C. 5, İstanbul, 1969, s. 1619; Nurdoğan Taçalan; Ege'de Türk Kurtuluş Savaşı Başlarken, İstanbul, 1970, s. 143 v.d.; Nail Moralı; Mütarekede İmir Olayları, Ankara, 1973. 
Mondros sonrasında İngilizler İzmir ve çevresini İtalyanlara bırakmak istememekteydiler. Diğer taraftan Yunanistan Başbakanı Venizelos ise İzmir ve çevresini talep etmekteydi. Nitekim Venizelos daha 2 Kasım !918'de Anadolu'nun batı kısmını Yunanlılara terkini istedi. ${ }^{11}$

Diğer taraftan Mondros Mütarekesi'nden sonra İtilaf Devletlerinin tutum ve davranışlarından da cesaret alan yerli Rumlar özellikle nüfus olarak kalabalık bulundukları şehir ve kasabalarda başına buyruk hareket etmeğe başlamışlardı. Hatta Ege Bölgesinde Rum çete faaliyetleri Mütarekeden hemen önce başlamıştı. ${ }^{12}$

Bu sırada Mütareke öncesinde savaş sebebiyle başka mahallere sevk ve iskân edilen ahalinin memleketlerine dönmelerine müsaade eden Hükümet, şimdi Mütareke sonrasında I. Dünya Savaşı sonunda Rusya'ya veya başka yabancı ülkelere kaçmış bulunan, adam öldürmüş veya bu derecede suç işlemiş olanlarla, Ülkenin sükun ve güvenini bozmaları ihtimali olan ve "Pasaport Kanununun 3. Maddesine nazaran" Ülkeye girmeleri yasaklananlar hariç diğerlerinin Ülkeye girmelerine müsaade etmek zorunda kalmaktaydı. ${ }^{13}$ Ayrıca 18 Ocak 1919 da toplanan Paris Barış Konferansı da, göç etmiş olan Ermeni ve Rumların yerlerine dönmeleri konusunu ele alarak bu yönde karar almıştı. ${ }^{14}$

İşte bu çerçevede Rum Patrikhanesinden yönlendirilen ve Etnik-i Eterya Cemiyetinin şubesi şeklinde çalışan başkanlığını Yunanlı Manuel Sozokos adlı birinin yaptığı Kordos Komitesi (Rum Muhacirleri Merkez Komisyonu) ile Mavri Mira Cemiyeti Adalardan ve Yunanistan'dan göçmen gibi gelen örgüt mensuplarını ayrıca I. Dünya Savaşında Anadolu'dan firar edip Yunan ve İtilaf Devletleri safında savaşmış Rumları Türkiye'ye sokup Anadolu'nun çeşitli yerlerine göndermekteydi. ${ }^{15^{3}} \mathrm{Bu}$ şekilde I. Dünya Savaşı öncesinde İzmir Metropolitliği görevinde bulunmuş, Makedonya'da Türklere karşı faaliyet göstermiş olan Hrisostomas şimdi 1 Ocak 1919'da tekrar İzmir'e geldi. Bu kişi İzmir'e gelir gelmez ilk iş olarak Rumları teşkilatlandırma çalışmalarına başladı. Bu faaliyetler çerçevesinde İzmir'de, İstanbul'daki Mavri Mira'ya benzer bir heyet oluşturuldu. Ayrıca Hrisostomas Yunan Hükümeti desteğinde İzmir, Aydın, Manisa, Balıkesir bölgelerinde Rum

"Jaeschke; a.g.e., s. 60-63; TïH; C. 2, s. 12-16; Yunan istekleri ile ilgili geniş bilgi için bkz. Michael Llewelyn Smith; Anadolu Üzerindeki Göz, İstanbul, 1978, s. 84-85; Dimitri Kitsikis; Yunan Propagandası, Meydan Neşriyatı, Baskı yeri ve yılı bellı değil, s. 32.

${ }^{12}$ Tansel; a.g.e., C. 1, s. 93.

${ }^{13}$ Recep Karacakaya; Kaynakçalı Ermeni Meselesi Kronolojisi (1878-1923) İstanbul 2001 s.139-140; Sina Akşin; İstanbul Hükümetleri ve Milli Mücadele, C.1 İstanbul 1992 s. 32-33; Jaeschke; a.g.e. s. 36-37.

${ }^{14}$ HTVD (Harp Tarihi Vesikaları Dergisi) S. (Sayı) 45 Belge 1050; BOABEO (Başbakanlık Osmanlı Arşivi Bab-l Ali Evrak Odası) Umumi No: 343317; Sofuoğlu; Kuvay-ı Milliye Dönemi... s. 38-39.

${ }^{15}$ BOABEO Umumi No: 343454; Tayyip Gökbilgin; Milli Mücadele Başlarken, C. 1 Ankara 1959 s. 154-155. 
çeteleri oluşturarak asayişi bozmak ve isyanlar hazırlamak için her türlü çareye başvurmağa başladı. ${ }^{16}$ Nitekim bu girişimlerin arkasından ve özellikle Paris Barış Konferansı'nda, Başbakan Venizelos tarafından ilk olarak 30 Aralık 1918'de Konferansa sunulan memorandumda ve bilahare 3-4 Şubat 1919 günlerinde "Onlar Şurası" huzurunda dile getirilen Yunan isteklerinin ki bu isteklerin arasında tabiatıyla Batı Anadolu da vardı, belirmesinden sonra Ege Bölgesinde Rum çete faaliyetleri gittikçe genişleme istidadı gösterdi. ${ }^{17} \mathrm{Bu}$ sırada Konferans Yunan isteklerini değerlendirmek üzere 5 Şubat'ta bir komisyon kurdu. Bilahare komisyon hazırladığ ${ }_{1}$ raporu 7 Mart'ta Konferansa ilgili komiteye sundu. Amerika ve İtalya temsilcileri komitede raporun Batı Anadolu'nun Yunanlılara bırakılması ile ilgili kısmına karşı çıktılar. Ancak Venizelos batı kıyısında bir açık liman kuracağına dair söz vererek Amerikalıları yatıştıracaktır. ${ }^{18}$ Bu sıralarda Batı Anadolu'ya yönelik girişimler çerçevesinde 20 Ocak 1919'da üç gezici ekip tertip etmek üzere bir Yunan hastane gemisi İzmir'e, arkasından 17 Şubat'ta bir müfreze askerle Kızılhaç heyeti maskesi altında Rum propagandist ve eylemci silah ve cephaneleriyle birlikte Ayvalık'a gelmişti. ${ }^{19}$ Sistemli bir şekilde gerçekleştirilen bu hareketlerle Yunanlılar, etrafa dehşet saçıp Türk ve Müslüman ahaliyi sindirerek öteye beriye dağılmasını istemekteydiler. Böylece Anadolu'ya sokulan Rumların iskanı kolaylaşacak, aynı zamanda Mondros Mütarekesi'nin yedinci maddesine işlerlik kazandırarak işgale zemin hazırlanacaktı. ${ }^{20}$ Ayrıca asayişsizliğin giderilmesi ancak Bölgenin Yunanistan'a verilmesiyle mümkün olacağı imajı oluşturulacaktı. Nitekim bu gelişmeler sırasında Rum Patrikhanesi, Paris'e gönderdiği Patrik Kaymakamı vasıtasıyla 16 Mart 1919'da Barış Konferansına, Rumlara tam bağımsızlık verilmesi ve ileride, doğuda asayişin temini için bağımsız idarelerin Yunanistan'a bağlanması talebiyle başvurdu. ${ }^{21}$

Gerçi bu sırada bu olayları ve gelişmeleri engellemek üzere Harbiye Nezareti'nin teklifi üzerine Hükümet, Nisan 1919 da silah, cephane ve üniformanın ülkeye sokulmasının meni, Osmanlı Tebaasından olmayan sivil yabancıların seyahat maksadıyla ülkeye gelmeleri hakkında bazı kayıt ve şartların tatbiki, Balkan Muharebesi'nden sonra Yunanistan ve Bulgaristan Hükümetleri ile akdedilen antlaşmalar gereğince mübadele olunan ahalinin

${ }^{16}$ Bayar; a.g.e., C. 5, s. 1606 ve 1638-1639.

${ }^{17}$ TïH; C. 1, s. 136; Taçalan; a.g.e., s. 161 v.d.; Sofuoğlu; Kuvay-ı Milliye Dönemi..., s. 38-39 ve 49-50; Jaeschke; a.g.e., s. 61; Yunan talebi için ayrıca bkz. Laurance Evans; Turkiye'nin Parçalanması ve ABD Politikası (1914-1924), İstanbul, 2003, s. 130.

${ }^{18}$ Evans; a.g.e., s. 130-131; Sonyel; a.g.e., C. 1, s. 51-52; Smith; a.g.e., s. 85.

${ }^{19}$ Jaeschke; a.g.e., s. 65; TiH; C. 1, s. 133-137.

${ }^{20}$ Mavri Mira hakkında geniş bilgi için bkz. Atatürk; a.g.e. C.3 vesika 1; Tansel; a.g.e. C.1 s. 92-95; Yunan talepleri ve Patrikhanenin faaliyetleri ve Mavri Mira için bkz. Adnan Sofuoğlu; Fener Rum Patrikhanesi ve Siyasi Faaliyetleri, İstanbul 1996 s. 81 v.d. Megali İdea için bkz. 22 v.d. ile Sofuoğlu; Kuvay-ı Milliye Dönemi... s. 31 v.d.

${ }^{21}$ Sofuoğlu; Kuvay-ı Milliye Dönemi..., s. 41; Gökbilgin; a.g.e., C. 1, s. 59-60. 
ülkeye dönmelerinin meni kararlarını ald.$^{22}$ Ancak Mütareke ortamı içinde Hükümetin aldığı bu kararları ne derece uygulayabileceği de ortadaydı.

Diğer taraftan 17-19 Mart 1919 tarihleri arasında İzmir'de, İzmir Müdafaa-1 Hukuk-u Osmaniye Cemiyeti, ağırlıklı olarak İzmir'in Yunanlılara verilmesine karşı alınacak tedbirleri görüşmek üzere Aydın vilayeti ile Karesi (Balıkesir) ve Menteşe (Muğla) sancaklarından 165 delegenin iştirak ettiği bir bölgesel kongre topladı. ${ }^{23}$ Bütün bunlara karşılık bölgede Yunan faaliyetleri bütün hızıyla devam ediyordu.

Bölgede bu gelişmeler olurken 28 Mart'ta Antalya'ya asker çıkaran İtalyanlar da Aydın ve çevresinde etkinlik kurmağa çalışmaktaydılar. ${ }^{24}$ Bunların yanı sıra İtalya, Konferansta Fiume ve İzmir hakkındaki taleplerini gerçekleştirmeğe çalışmaktaydı. Ancak İtalya, her iki mesele ile ilgili olumlu gelişme sağlayamayınca 24 Nisan'da Konferansı terk etme kararı aldı. Bu karar doğrultusunda İtalyan delegasyonu Konferansı terk ederek İtalya'ya döndü. ${ }^{25} \mathrm{Bu}$ gelişmenin arkasından İtalya 2 Mayıs'ta Fiume'ye bir savaş gemisi, İzmir'e küçük bir filo gönderdi. Bunun üzerine İngiliz ve Fransız savaş gemileri İtalyanları göz altında bulunmak üzere adı geçen yerlere gönderildi. Bu sırada Güney Anadolu'da işgal bölgelerini genişleten İtalyanların, İzmir'i de işgal niyetinde oldukları söylentileri çıktı. Bu gelişmelerden yararlanmak isteyen Venizelos'un girişimleri, yine aynı şekilde Lloyd George'nin İtalyanların İzmir'e çıkmalarını önlemek üzere Yunan ordusunun İzmir'e çıkarılması yönündeki öğütleri üzerine, 6 Mayıs'ta toplanan üç büyükler yani ABD, İngiltere, Fransa İzmir'in Yunanlılarca işgalini kararlaştırdılar. ${ }^{26}$ Bu sırada 7 Mayıs'ta İtalyanlar, Konferansa döndülerse de İzmir'le ilgili gizli görüşmelere çağrılmadılar. Bu şekilde 7-10 Mayıs tarihleri arasında gerçekleştirilen toplantılarda İzmir'e yapılacak çıkarmanın ayrıntıları görüşüldü. Nihayet 14 Mayıs sabahı Amiral Webb İstanbul'da Damat Ferit Paşa'ya İzmir tabyalarının işgal edileceğine dair notayı verdi. Bu gelişmenin akabinde İngiliz Amirali Calthorpe de aynı mahiyetteki notayı İzmir Valisi İzzet Bey ile 17. Kolordu Kumandanı Ali Nadir Paşaya verdi. ${ }^{27}$

Bu son gelişmelerden haberdar olan İzmir Türk halkı, derhal Redd-1 İlhak cemiyeti oluşturarak 14-15 Mayıs gecesi Bahri Baba parkının olduğu yerde toplanıp protesto gösterilerinde bulundular. Ayrıca bu toplantıda işgale

${ }^{22}$ BOABEO Umumi No: 345376; Gökbilgin; a.g.e. s. 60-62.

${ }^{23}$ Bayar; a.g.e., C. 5, s. 1606; Taçalan; a.g.e., s. 193-194; Moralı; a.g.e., s. 13-14; Sofuoğlu; Kuvay-ı Milliye Dönemi..., s. 51-52.

${ }^{24}$ Sofuoğlu; Kuvay-ı Milliye Dönemi ..., s. 52-53.

${ }^{25}$ Evans; a.g.e., s. 160-165.

${ }^{26}$ Evans; a.g.e., s. 166-167; Sonyel; a.g.e., C. 1, s. 52; Smith; a.g.e., s. 90-93.

${ }^{27}$ Akşin, a.g.e., s. 266; TiH; C. 2, Kısım 2, s. 47 v.d.; Sofuoğlu; Kuvay-ı Milliye Dönemi..., s. 55-57. 
IZMIR ISSGALI SONRASINDA YUNANLILARIN BATI ANADOLU'DA.... 137

karşı direnme ve mücadele kararı verdiler. Ancak o an için bir sonuç almalar1 güçtü. ${ }^{28}$

Nitekim 15 Mayıs sabahı Yunan birlikleri İngiliz Fransız ve Yunan gemilerinin koruması altında İzmir'e çıktılar. Bu sırada limanda bulunan Amerikan Filosu da İtalyanları göz altında tutmakla meşguldü. Karaya çıkan Yunan birlikleri yerli yani Osmanlı vatandaşı olan Rumlar tarafından alkışlar, ellerinde çiçekler ve Yunan bayrakları olduğu halde büyük gösterilerle karşılandı. Bu arada İzmir Metropoliti Hrisostomas karaya çıkan ilk Yunan taburunu takdis etti. Bu gelişmeler Türkler arasında büyük infial uyandırmaktaydı. Nitekim Şehre doğru ilerleyen Yunan Alayı Kemeraltı mevkiine gelince bir silah sesi duyuldu. Alayın önünde bayrağı taşıyan Yunan askeri vurulmuştu. Böylece işgale karşı ilk kurşun sıkılmış olmaktaydı. Ancak bu olayı bahane eden Yunanlılar ve onlarla birlikte hareket eden yerli Rumlar şehirde büyük bir katliama giriştiler. ${ }^{29}$

\section{IŞGALIN YAYILMASI VE IŞ̧GALE KARŞI MILLI DİRENIŞ}

İzmir şehrini işgal eden Yunan birlikleri burada durmayıp derhal Anadolu içlerine doğru ilerlemeğe başladılar. Bu şekilde Yunanlılar, 17 Mayıs'ta Urla ve Çeşme'yi işgal ettiler. Arkasından biri deniz yoluyla Ayvalık istikametine olmak üzere İzmir'in doğusu ile kuzeyine doğru üç koldan ilerleyerek, 21 Mayıs'ta Menemen'i, 22 Mayıs'ta Selçuk'u, 26 Mayıs'ta Manisa'yı, 27 Mayıs'ta Aydın'1 28 Mayıs'ta Tire'yi, 29 Mayıs'ta Turgutlu'yu işgal ettiler. Bu sırada 29 Mayıs'ta Ayvalık'a çıkarma yapan Yunanlılar, bilahare burada Ali Bey Komutasındaki 172. Alayın direnişine rağmen burayı da işgal ettiler. Arkasından 1 Haziran'da Ödemiş'i, 3 Haziran'da Nazilli'yi, 4 Haziran'da Ahmetli'yi, 12 Haziran'da Bergama'y1 da işgal ettiler. ${ }^{30} \mathrm{Bu}$ işgaller Türk topraklarının elden gitmeğe başladığını gösteren çok önemli bir gelişmeydi. Yunanlıların bu işgallerine karşı alelacele oluşturulan milli kuvvetler direniş gösterdi ve şiddetli çatışmalar oldu. Nitekim bu çerçevede sivil katkılı ilk direniş Urla'da meydana geldi. Diğer taraftan 16 Mayıs'ta sayıları 800'ü bulan Rum çeteleri Türk köylerine saldırıp yakıp yıkmağa ve yağmaya başladılar. Bunun üzerine 173. Piyade Alayı Komutanı Yarbay Kazım Bey halkla işbirliği sonucu temin ettiği yardımla elinde bulunan az sayıdaki kuvvetle Rum çetelerine karşı koydu. ${ }^{31}$

${ }^{28}$ Taçalan; a.g.e., s. 215 v.d.; Sofuoğlu; Kuvay-ı Milliye Dönemi..., s. 57-58; Bilge Umar; Izmir'de Yunanlıların Son Günleri, Ankara, 1974, s, 98 v.d.

${ }^{29}$ Evans; a.g.e., s. 175-176; TiH; C. 2, Kısım 1, s. 54-55; İlk kurşun olayı ve Yunan katliamı için bkz. Bayar; a.g.e., C. 6, s. 1796; Umar,,; a.g.e., s. 119 v.d.; Kayhan Sağlamer; “Anadolu'nun İşgali ve Yunan Mezalimi”, Belgelerle Türk Tarihi Dergisi, Sayı 49, Ekim 1971; Apak; a.g.e., s. 12-14; Sofuoğlu; Kuvay-ı Milliye Dönemi..., s. 59-60.

${ }^{30}$ Utkan Kocatürk; Atatürk ve Türkiye Cumhuriyeti Tarihi Kronolojisi 1918-1938, Ankara, 1988 , s. 40 v.d.

${ }^{31}$ Sitkı Aydınel; Güneybatı Anadolu'da Kuvay-t Milliye Hareketleri, Ankara 1990, s. 72. 
Bu gelişmelerin yanı sıra İzmir'in ve çevresinin işgali tüm ülke çapında dehşet ve üzüntü meydana getirdi. Başta İstanbul olmak üzere Anadolu'nun hemen her yerinde protesto gösterileri ve mitingler tertiplendi. Ayrıca işgali protesto eden telgraflar hemen her tarafa gönderildi. ${ }^{32}$

Bunların yanı sıra yukarıda değinildiği gibi İzmir işgalinin İzmir şehri ile sınırlı kalmayıp çevreye yayılma istidadı göstermesi ve katliama dönüşmesi üzerine Harbiye Nezareti 16 Mayıs'ta bölgedeki bütün birliklere bir genelge yayınlayarak, Yunan asker ihracı karşısında birliklerin mevkilerini terk etmeyerek yerlerinde kalmalarını, bir emrivaki halinde bir silahsızlandırma gibi bir muameleye maruz kalmamaları için tüm kıtaatın toplu halde ve silah başında bulunmasını istedi. Aynı şekilde 19 ve 20 Mayıs tarihlerinde Şevket Turgut Paşa İzmir işgali üzerine alelacele Tekirdağ'dan Bandırma'ya nakledilen 14. Kolordu ve İzmir'de bulunan 17. Kolordu ile yine bölgede bulunan 57. Furkaya gönderdiği genelge ile aynı mahiyette isteklerde bulunduğu gibi şayet çekilme zorunda kalınırsa askerlik şubelerinin yerinde kalması, muhacerete fırsat verilmemesi bunu için işgal edilen yerlerin en azından idarenin terk edilmemesinin sağlanmasını istedi. ${ }^{33}$ Yine 22 Mayıs'ta Erkan-1 Harbiye-i Ümmiye Reisi Cevat Paşa, Batı Anadolu'daki birliklere gönderdiği genelge ile, “...Devletin Yunanlılara kaptıracak ne fazla bir silahı nede fişeği var." diyerek hiçbir dağdağaya meydan vermeden tehlike altındaki silah ve cephanenin emin bölgelere nakledilmesini istedi ${ }^{34} \mathrm{Bu}$ arada Harbiye Nezareti işgal sonrası dağılma tehlikesiyle karşı karşıya kalan 17. Kolorduyu yeniden derleyip toparlamak üzere Kolordunun 56. Firkası Komutanı göreviyle Albay Bekir Sami Bey’i (Günsav) Batı Anadolu'ya gönderdi. ${ }^{35}$

$\mathrm{Bu}$ arada bölgedeki bir kısım komutanlardan işgallere karşı alınabilecek tavırla ilgili görüş ve teklifler de gelmekteydi. Nitekim daha İzmir'in işgalinin başladığı gün olan 15 Mayıs’ta Burdur Askerlik Şubesi Başkanı İsmail Hakkı Bey 57. Fırka Komutanı Albay Şefik Bey'e halkın çoğunluğuna dayanacak bir teşkilat yapılıp, bunların elden geldiğince el altından silahlandırılmasını önerdi. Ayrıca 12. Tümen dairesinde 20000 mükellefiyet meyanında gönüllü ve fedai teşkilatın yapılmasının mümkün

${ }^{32}$ İzmir'in ișgali ve diğer işgaller ile direnişler hakkında geniş bilgi için bkz. Gökbilgin; a.g.e., C. 1, s. 122 v.d.; Jaeschke; a.g.e., s. 85-88; TiH; C. 1, Kısım 1, s, 64 v.d.; Sofuoğlu; Kuvay-ı Milliye Dönemi..., s. 89 v.d. İşgali protesto mitingleri için bkz. Kemal Arıburnu; İstanbul Mitingleri, İstanbul, 1975; Gökbilgin; a.g.e., C. 1, s. 87 v.d.; Özalp; a.g.e., C. 1, s. 20-23.

${ }^{33}$ Rahmi Apak; Garp Cephesi Nasıl Kuruldu, Ankara, 1990, s. 30-31; Kazım Özalp; Milli Mücadele, Ankara, 1985, C. 2, s. 2-5 belge 2 ve 3; M. Şefik Aker; Istiklal Harbinde 57. Tümen ve Aydın Milli Cidali (104 Sayılı Askeri Mecmuanın Tarih Kısmı), C. 1, Ankara, 1937, s. 69 ve 87.

${ }^{34}$ Özalp; a.g.e., C.2, s. 18 belge 7.

${ }^{35}$ Bekir Sami Bey'in bölgedeki faaliyetleri için bkz. Sofuoğlu; Kuvay-ı Milliye Dönemi..., s. 116 v.d. 
olduğunu ifade ederek, her şube dairesinde mülki ve askeri idareler marifetiyle gizli yapılacak milli direniş merkezlerinin teşkilatın çekirdeği olacağını belirtti ${ }^{36}$ Çünkü bu sırada yalnızca askeri birliklerin direniş göstermesi, hem mütareke açısından hem de askeri birliklerin olumsuz propaganda neticesi firarlar ve Mütareke gereği yapılan terhisler sebebiyle sayıları iyice azalıp kadro haline gelmiş olduğundan mümkün değildi ${ }^{37} \mathrm{Bu}$ sebeple Albay Şefik Bey İzmir işgali sonrasında Harbiye Nezaretine gönderdiği raporda bölgenin genel durumunu anlattıktan sonra daha önce kendisine teklif sunmuş olan İsmail Hakkı Bey'in görüşleri doğrultusunda Kuvay-1 Milliye teşkilatı oluşturmanın işgallere karşı en iyi tedbir olacağını belirtti. ${ }^{38}$ Erkan-1 Harbiye Reisi Cevat Paşa da rapor üzerine kayıt düşerek bu fikri benimsedi. Cevat Paşanın kaydı ve dolayısıyla Kuvay-ı Milliye düşüncesi basında da yer ald.$^{39}$

Yine aynı günlerde yani İzmir'in işgali üzerine önce Menemen'e geçip oradan da Bandırma'ya hareket eden Kazım Bey (Özalp) yol boyunca uğradığı Manisa, Kırkağaç, Soma, Balıkesir'de İzmir'in işgalini anlatarak belediye başkanlarından direniş için Redd-i İlhak teşkilatı kurmalarını istedi ${ }^{40}{ }^{40}$ Diğer taraftan bölgede kurulmuş olan Müdafaa-1 Hukuk Cemiyetleri de işgallere karşı direnmek için silahlı direniş gurupları oluşturmağa çabalıyorlardı. ${ }^{41}$

Bütün bu girişimlerin sonucunda Ayvalık Mevkii Kumandanı Ali Bey, Yunanlıların 29 Mayıs'taki Ayvalık işgali girişimine bölgede oluşturulan Milli Kuvvetlerle birlikte direniş gösterecektir. ${ }^{42} \mathrm{Bu}$ şekilde bölgede bir Kuvay-1 Milliye hareketi oluşacaktır. Aynı zamanda Yunan işgallerine karşı Ayvalık, Akhisar ve Soma'da bir savunma cephesi de oluşturulacaktır. Daha sonra da oluşturulan cephelerin tertibi ve kuvvetlendirilmesi, ayrıca Milli Kuvvetlerin sevk ve idaresi ile onların her türlü ihtiyaçlarının karşılanmasının organize edilmesi, aynı zamanda kendi teşkilatlanmalarının yaygınlaştırılıp kuvvetlendirilmesi için Müdafaa-1 Hukuk ve Redd-1 İlhak cemiyetleri bölgede kongreler toplama yoluna gitti. Bu şekilde Balıkesir, Alaşehir Nazilli'de çeşitli tarihlerde kongreler toplanarak, Heyet-i

\footnotetext{
${ }^{36}$ Sofuoğlu; Kuvay-ı Milliye Dönemi..., s. 65 .

${ }^{37}$ Aker; a.g.e., s. 80 v.d.

${ }^{38}$ Aydınel; a.g.e., s. 75; Doğan Avcıoğlu; Milli Kurtuluş Tarihi, İstanbul, 1974, s. 1239-

${ }^{39}$ Sofuoğlu; Kuvay-ı Milliye Dönemi ..., s. 68.

${ }^{40}$ Özalp; a.g.e., C. 1 , s. 9.

${ }^{41}$ Bu çabalar için bkz. İlhan Tekeli-Selim İlkin; Ege'de Sivil Direnişten Kurtuluş Savaşına Geçerken, Uşak Heyet-i Merkeziyesi ve İbrahim (Tahtakılıç) Bey, Ankara, 1989, s.

${ }^{42}$ Özalp; a.g.e., C. 1, s. 15; Sofuoğlu; Kuvay-ı Milliye Dönemi ..., s. 68-69.
} 1240. $62-63$. 
Merkeziye oluşturulacak ve kongrelerde alınan kararlar uygulamağa konulacaktır. ${ }^{43}$

$\mathrm{Bu}$ gelişmeler ve işgale karşı oluşan mukavemet karşısında bölgede bulunan İngiliz subayları, bu havayı kırmak üzere işgalin geçici olduğu propagandasını yapmağa başladılar. Bu şekilde bir taraftan işgallere karşı direniş ve çatışmalar sürerken, diğer taraftan İtilaf Devletleri adına görevlendirilen Karadeniz Ordusu Başkumandanı General Milne'nin girişimleriyle resmi makamlar nezdinde yapılan görüşmeler sonucu, Milne Hattı olarak bilinen, Ayvalık- Kozluca ile Manisa'nın kuzeyinden, SomaAkhisar ile Salihli'nin batısından, Aydın ile Ödemiş'in doğusundan geçip Büyük Menderes Boyunca uzanan hat boyunca işgal sınırlandırılarak, çatışma durdurulmağa çalışılacaktır. ${ }^{44}$

YUNANLILARIN IŞGAL ALTINDA TUTTUKLARI BÖLGELERDEKİ UYGULAMALARI

Yunanlılar, İzmir işgalinden hemen sonra bölgeyi Yunanistan'a ilhakı gaye edinen davranışlar içine girdiler. İzmir işgalinden kısa bir süre sonra Venizelos'un yakın arkadaşı Giritli bir avukat Aristidis Stergiadis Yunanlı İzmir işgal kuvvetleri komutanının siyasi temsilcisi olarak atandı. Hem genel vali hem de Fevkalade Komiser olarak olağanüstü yetkilere sahip olan bu kişi 21 Mayıs'ta İzmir'e geldi. ${ }^{45}$

İzmir işgali sonrasında Yunan işgal kuvvetleri komutanlığı merkezi İzmir'de oluşturulmuştu. Merkez komutanlığın emrinde İzmir'de Mevki Komutanlığı, İnzibat Askeri Komutanlığı, Topçu Komutanlı̆̆ı, Askeri Hekimler Şubesi Müdürlüğü, Telefon ve Telgraf, İnşaat İşleri, Sağlık, Nakil Araçları şube müdürlükleri bulunmaktaydı. Ayrıca yukarıda belirtildiği gibi bölgedeki işgali yaygınlaştıran Yunanlılar Manisa'daki birliklerini de tümen seviyesine çıkarmışlardı. Bölgedeki 2. Kolordularının karargahı da Manisa'da idi. ${ }^{46}$ Bunun yanında Stergiadis'in İzmir'e gelmesinden sonra ise Fevkalade Komiserlik teşkilatı oluşturuldu. Oluşturulan bu teşkilatın da içişleri, dışişleri, eğitim, bayındırlık, liman, gümrük, ekonomi, tazminat, iaşe, muhacirler, muhasebe, mal sandığı, haberleşme, tercüme, hukuk müşavirliği ve ziraat bankası işlerini incelmekle görevli çeşitli şubeleri vardı. Bunların yanında Manisa ve Aydın sancaklarıyla Ödemiş, Menemen, Bergama ve Turgutlu kasabalarında da bir Yunanlı sivilin bulunduğu birer siyasi temsilcilik oluşturuldu. Ayrıca Çeşme, Karaburun ve Foça ilçelerinde

\footnotetext{
${ }^{43}$ Oluşturulan cepheler ve kongreler için bkz. Sofuoğlu; Kuvay-l Milliye Dönemi..., s. 135 v.d.; Özalp; a.g.e., C. 1, s. 34 v.d.; Şerafettin Turan; Balıkesir ve Alaşehir Kongreleri ve Hacım Muhittin Çarıklının Kuvay-ı Milliye Hatıraları, Ankara, 1967.

${ }^{44}$ Milne Hattı hakkında geniş bilgi için bkz. Sofuoğlu; Kuvay-ı Milliye Dönemi..., s.

${ }^{45}$ M. Kamil Su; Sevr Antlaşması ve Aydin (Izmir) Vilayeti, Ankara, 1991, s. 6-7.

${ }^{46}$ Su; a.g.e., s. 7; Nusret Köklü; Manisa İsgalden Kurtuluşa, Ankara 1976, s. 61.
} 222 v.d. 
birer iskan ve muhacirler memuru görevlendirildi. ${ }^{47} \mathrm{Bu}$ örgütlenmelerin yanı sıra Yunanlılar işgal bölgelerinde sıkıyönetim mahkemeleri oluşturarak, Osmanlı Devleti'nin kaza hakkını hiçe sayıp bütün suçlara hatta hukuk işleriyle ilgili davalara da bakmağa başladılar. Bu şekilde Yunanlıların İzmir işgali askeri işgal niteliğini kaybederek bölgede yeni bir yerel yönetim oluşturma şekline girmişti ki, bütün bu girişimler, esasında Mondros Mütarekesine aykırı idi. Çünkü Mütarekeye göre işgal kuvvetleri yerel yönetime karışmak ve memurları değiştirmek hakkına sahip değillerdi. ${ }^{48}$

$\mathrm{Bu}$ girişimlerinin yanı sıra Yunanlılar, işgal öncesinde olduğu gibi şimdi işgal sonrasında da üstelik bölgede denetim sağladıkları için daha bir kolaylıkla Ayvalık ve Çanakkale taraflarından ağırlıklı olmak üzere Batı Anadolu'ya Rumları sokmayı devam ettirdiler. Bu şekilde bölgede nüfus yoğunluğu sağlanmağa çalışılıyordu. ${ }^{49}$

Yunanlılar, bu girişimlerini Sevr Antlaşması arifesinde ve özellikle sonrasında arttırarak devam ettirdiler. Nitekim Sevr Antlaşmasının imzalanmasından hemen sonra ki, Antlaşma hükmüne göre Aydın (İzmir) Vilayeti topraklarından bir kısmının yönetimi, Yunanlıların hazırlayacağı ve Milletler Cemiyetinin onaylayacağı seçim kanunu ile seçilecek yerel meclisin beş yıl sonunda Yunanistan'a katılıp katılmayacağı hakkında yapacağı oylamaya kadar Yunanistan'a birakılmaktaydı, 11 Ağustos'tan itibaren daha evvelden kontrol altına aldıkları hükümet dairelerine şimdi el koymağa başladılar. Bu çerçevede İzmir işgalinden bir müddet sonra İstanbul Hükümetince görevden alınan İzzet Bey'e vekalet etmekte olan Defterdar Ahmet Asım Bey'in görevine son verdiler. Yerine İstanbul Hükümetinin atadığı valileri de İzmir'e sokmadılar. Şimdi ise İşgal altındaki bölgeler Stergiadis tarafından genel vali gibi yönetilmeğe başlandı. Daha sonra ise tüm daireler de geniş ölçüde bir düzenleme hareketine girișildi. Okullarda müfredat programının değiștirilmesi ve zorunlu Yunanca dersi okutulmasına kadar eğitim işlerine müdahale edildi. 1921 yılından itibaren de tüm memurların maaşları Yunan parası Drahmi ile ödenmeğe başlandı. Bütün bunların yanı sıra özellikle 22 Haziran 1920'de başlayan Yunan harekatı sırasında bölgedeki Müslüman halk göçe zorlandı. Bu şekilde göç eden Müslümanların sayısı elli bine ulaşmaktayd $1 .{ }^{50}$ Sakarya Muharebesi esnasında 17 Ağustos'ta Yunan basını Yunan işgali altındaki topraklarda Yunan Yüksek Komiserinin sivil idaresiyle çalışacak bir Yunan Askeri İdaresi kurulduğunu ilan etmişlerdi. Sakarya Muharebesinden sonra ise Yunanlılar, 21 Ekim'de Fransa Hükümetine, 27 Ekim'de İngiliz Hükümetine

\footnotetext{
${ }^{47} \mathrm{Su}$; a.g.e., s. 8 .
}

${ }^{48} \mathrm{Su}$; a.g.e., s. 6-8; Sofuoğlu; "Yunanlıların Batı Anadolu'ya Yerleşme Girişimleri (İlhak Çabaları) ve İyonya Devleti Macerası" Prof. Dr. M. Abdulhaluk Çay Armağanı, C. 2, Ankara, 1998, s. 854-855.

${ }^{49}$ Sofuoğlu; Yunanlıların Batı Anadolu'ya..., s. 855.

${ }^{50}$ Geniş bilgi için bkz. Su; a.g.e., s. 10 v.d.; Sofuoğlu; Yunanlıların Batı Anadolu'ya..., s. 855 v.d. 
Batı Anadolu'da Yunan Sivil İdaresi kurmayı düşündüklerini söylediler. ${ }^{51}$ Nitekim bir müddet sonra İzmir'deki Fevkalade Komiserinin unvanını genel valiliğe çevirerek işgal altındaki bölgede tamamen Yunan kanun ve nizamlarını uygulamağa başladılar. ${ }^{52}$

Ancak özellikle Sakarya Muharebesi sonrası Anadolu'daki durum değişecek ve yavaş yavaş inisiyatif Ankara Hükümetinin eline geçecektir. Bu gelişme ise yerli Rumlar ile Yunanistan'ı bölgede yeni arayışlara ve girişimlere sevk edecektir. Bu çerçevede Kasım 1921'den itibaren oluşturdukları Müdafaa-i Milliye Komitesi vasıtasıyla başlattıkları Küçük Asya Hareketi ile bölgede İyonya Devleti oluşturmaya girişeceklerdir. ${ }^{53}$

Bütün bu gelişmeleri, İstanbul Hükümeti ancak ve sadece İtilaf Devletlerinin İstanbul'daki Fevkalade Komiserlikleri ile Kendi büyük elçileri vasitasıyla diğer devletler nezdinde protesto etmiş, başkaca bir şey yapamamıştır. Diğer taraftan Ankara Hükümeti ise İstanbul Hükümetinin imzaladığı Sevr Antlaşmasını kesinlikle kabul etmeyip tanımıyor, İzmir Bölgesinde başlayan ve gittikçe genişleyen Yunan işgaline karşı da askeri ve diplomatik girişimlerini sürdürerek, bu yönde her türlü tedbirleri alıyordu. ${ }^{54}$

\section{SONUÇ}

Yunanlıların bu girişimleri esasında bölgeyi Yunanistan'a bağlamak yani enosis politikalarının bir sonucuydu. O sıralarda Yunanlıların bu politikalarının önü ancak başarılı bir askeri harekatla kesilebilirdi. Bu bakımdan Ankara Hükümeti Sakarya Muharebesinin ardından bir yandan diplomatik girişimlerini sürdürürken bir yandan da büyük bir gizlilik içinde Yunanlıları Anadolu'dan söküp atmak için askeri hazırlıklarını sürdürmekteydi. Nihayet Türk ordusu tüm diplomatik girişimlerin tıkandığ 1 anda 26 Ağustos 1922'de Yunan kuvvetlerine karşı büyük bir taarruz başlattı. Kesin bir zaferle sonuçlanan bu Büyük Taarruz sonucunda ki İzmir Metropoliti Hrisostomas 'Küçük Asya'da Hellenizm, Yunan Devleti ve tüm Yunan Milleti, şimdi artık hiçbir gücün kendilerini kurtaramayacağı bir cehenneme doğru yol almaktadır..." ${ }^{55}$ diyerek son bir çırpınışla Rumlar adına Venizelos'tan girişimde bulunmasını isteyecektir, Yunanlılar Anadolu'dan tamamen atıldılar. Böylece Sevr Antlaşması ortadan kaldırıldığı gibi, bu sonuçla Yunanlıların Batı Anadolu'ya yönelik Enosis politikaları da sona erdirildi.

${ }^{51}$ Bilal N. Şimșir; Ingiliz Belgeleriyle Sakarya'dan İzmir'e, (1921-1922) Ankara, 1989, s. 293-294

${ }_{52}^{52}$ Sofuoğlu; Yunanlıların Batı Anadolu'ya..., s. 862.

${ }^{53}$ Geniş bilgi için bkz. Sofuoğlu; Yunanlıların Batı Anadolu'ya ..., s. 865 v.d.

${ }^{54}$ Sofuoğlu; Yunanlıların Batt Anadolu'ya..., s. 862-863.

${ }^{55}$ David Fromkin; Barışa Son Veren Barış, Modern Ortadoğu Nasıl Yaratıldı? 19141922, Çeviren: Memet Harmancı, İstanbul, 1994, s.548-549. 